E3S Web of Conferences 1, 23005 (2013)

DOI: $10.1051 / \mathrm{e} 3$ sconf $/ 20130123005$

(C) Owned by the authors, published by EDP Sciences, 2013

\title{
Large Industrial Point Sources in Italy: a focus on mercury concentrations resulting from three seasonal ship-borne measurements
}

\author{
M. Bencardino $^{1}$, F. Sprovieri ${ }^{1}$ and N. Pirrone ${ }^{1}$ \\ ${ }^{1}$ CNR-Institute of Atmospheric Pollution Research, c/o: UNICAL-Polifunzionale, 87036 Rende ITALY, \\ bencardino@iia.cnr.it
}

\begin{abstract}
In Italy there are 25 Large Industrial Point Sources whose mercury emissions in air exceed the established threshold of $10 \mathrm{~kg} \mathrm{year}^{-1}$. Many of these mercury point sources, mostly distributed along the Italian coastal area, are located at sites qualified as National Interest Rehabilitation Sites because of documented contamination in qualitative and/or quantitative terms and of potential health impact. Atmospheric mercury emissions related to Italian Large Industrial Point Sources, with a value of $1.04 \mathrm{Mg} \cdot \mathrm{yr}^{-1}$ for 2007 , have a not negligible contribution, accounting, on their own, for more than $10 \%$ of the total mercury emissions resulting from all activity sectors at a national level. Among others, thermal power stations, pig iron and steel as well as basic inorganic chemical production, result to be the main contributing industrial activities. In order to assess how mercury species concentrations and distribution in the Marine Boundary Layer (MBL) change with vicinity to large industrial sites, measurements of atmospheric mercury were performed during three oceanographic campaigns aboard the Research Vessel (R.V.) Urania of the Italian CNR. Collection of GEM, GOM and PBM was conducted across the Adriatic sea, during autumn 2004 (27 $7^{\text {th }}$ of October to $12^{\text {th }}$ of November) and summer $2005\left(17^{\text {th }}\right.$ to $29^{\text {th }}$ of June), and across the Tyrrhenian sea during autumn 2007 (12 $2^{\text {th }}$ of September to $1^{\text {st }}$ October). Analysis were carried out with reference to the period in which the R.V. Urania has stopped close to the main Italian industrial contaminated sites. Explorative statistical parameters of atmospheric mercury species were computed over each single stop-period and then compared with the overall cruise campaign measurements. Results are herein presented and discussed.
\end{abstract}

Key words: mercury, industrial emissions, ship-borne measurements, cruise campaigns

\section{Introduction}

Emissions from large industrial point sources are currently regulated by the Directive 2008/1/EC of the European Parliament and of the Council concerning Integrated Pollution Prevention and Control (IPPC). The European register EPER (European Pollutant Emission Register), established within the Directive 96/61/EC and implemented by the Decision 2000/479/EC, represents the first step at a European level towards a truly integrated pollutant emissions register. This experience was then improved with the introduction of the E-PRTR (European Pollutant Release and Transfer Register) whose first reporting year refers to 2007. Concerning Italy, in accordance with European EPER, a national pollutant emission register has been established, called INES (Inventario Nazionale delle Emissioni e delle loro Sorgenti). INES has been operating since 2003 (first reporting year, 2002) and the last available updating refers to 2006. In order to check the atmospheric mercury emissions from all IPPC activities located in Italy, the INES and E-PRTR registers have been browsed and queried. Emissions referring to the same IPPC activity and for the same year were grouped, as reported in Fig.1, in order to assess trend in mercury emissions from 2002 to 2007 . As it can be note in this graph, total mercury emissions released from all IPPC activity showed an almost constant trend with a slight decrease from $2002\left(2.1 \mathrm{Mg} \mathrm{yr}^{-1}\right)$ to $2004\left(2.0 \mathrm{Mg} \mathrm{yr}^{-1}\right)$. An increase of $34.9 \%$, with a value of $2.7 \mathrm{Mg} \mathrm{yr}^{-1}$, was then observed in 2005 followed by a subsequent decrease in 2006 , with a total mercury emissions values of $2.3 \mathrm{Mg}$ $\mathrm{yr}^{-1}$. In 2007 there was a sharp decline with a value of 1.04

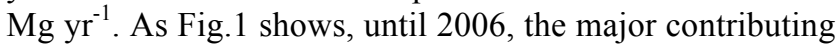
IPPC activity was that related to "Installations for the production of pig iron or steel" (IPPC code: 2.2) that, in 2006 , accounted for $64 \%$. Otherwise, in 2007 the main contributing industrial activity became the "Energy sector" (IPPC code: 1.1 and 1.2), with a contribution of $37.2 \%$ 
followed by "Chemical installations for the production of basic organic chemicals" (IPPC code: 4.1), with $32.6 \%$.

Comparing the absolute contribution from each single large industrial point source, it was evident that the highest value of mercury emissions in air, ranging from $1063 \mathrm{Kg} \mathrm{yr}^{-1}$ (2002) to $174 \mathrm{Kg} \mathrm{yr}^{-1}$ (2007), refers to ILVA S.p.a.. This is one of the largest pig iron and steel facility in Europe that is located in the city of Taranto and whose involved area has been defined as a National Interest Rehabilitation Site. The second large contribution, in terms of absolute mercury emission values, came from facilities both referring to installations for the production of basic inorganic chemicals. These latter refer to SYNDIAL S.p.A. - ex EniChem S.p.A located at Augusta-Priolo city, in Sicily, and to SYNDIAL S.p.A. located in Porto Marghera, Venice. Worth of note are also the thermal power stations located at Porto Torres, (Sardinia), Brindisi (Puglia) and Trieste (Friuli-Venezia-Giulia) and the refinery operating in Gela (Sicily). As Fig. 2 shows, all facilities just mentioned are distributed along the Italian coast and additionally they also coincide with those areas qualified as Contaminated Sites of National Interest (SINs), (Ministerial Decrees n. 486, 2001 and n. $308,2006)$. In order to assess how mercury species concentrations and distribution in Marine Boundary Layer (MBL) change with vicinity to industrial contaminated sites, measurements of atmospheric mercury were conducted during three oceanographic campaigns across both the Tyrrhenian and the Adriatic sea aboard the R.V. Urania of the Italian CNR.

\section{Materials and Methods}

Measurements of atmospheric mercury species were conducted across both the Tyrrhenian and the Adriatic sea aboard the R.V. Urania of the Italian CNR, during three oceanographic campaigns of which two were performed along the same route during two seasons, autumn (27 October to 11 November) 2004 and summer (17 to 29 June) 2005 whereas the third one took place during late summer-autumn (12 September to 1 October) 2007. The campaigns aimed to assess how mercury species concentrations and distribution in MBL with changing meteorology conditions and change with vicinity to industrial Contaminated Sites. The cruise paths of the Med-Oceanor campaigns are shown in Figure 5.5. The 2004 and 2005 cruise paths (solid and dotted white lines) were identical in the Adriatic, but the 2005 cruise started from Napoli and finished at Messina. The 2007 cruise campaign (dotted yellow line) was otherwise entirely performed in the Tyrrhenian sea. Collection and analysis of GEM (Gaseous Elemental mercury), GOM (Gaseous Oxidized Mercury) and PBM (Particulate Bound Mercury) was performed using an automated Tekran (Toronto, Canada) Model 2537A CVAFS, Tekran Model 1130 speciation unit, and Tekran Model 1135 system (Landis et al., 2002). The integrated mercury system was mounted on the top deck of the R.V. Urania with the inlet at about $10 \mathrm{~m}$ above the sea surface. GEM samples (5 min) were continuously quantified by the 2537A analyser. The technique is based on amalgamation on two $\mathrm{Au}$ traps within the analyser working alternately, and mercury detection by CVAFS.

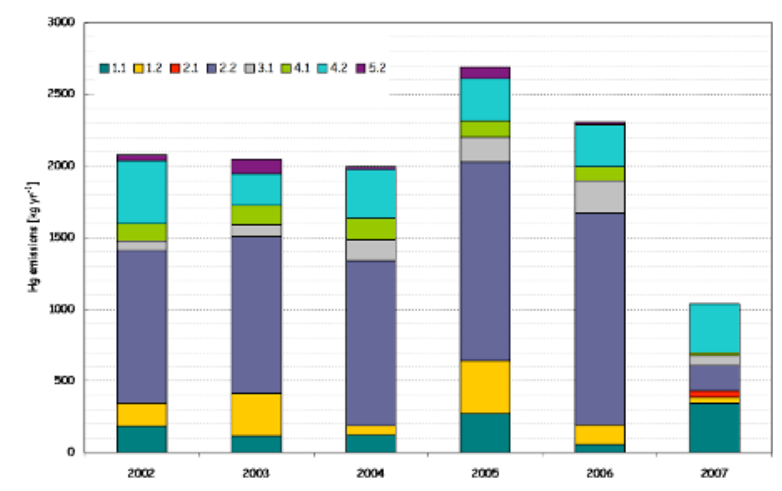

Fig. 1. Mercury emissions referring to IPPC activities as a whole, 2002-2007.

The integrated Tekran speciation system was configured to collect $2 \mathrm{~h}$ GOM and PBM samples on a quartz $\mathrm{KCl}$-coated annular denuder and quartz filter assembly, respectively. Particles larger than $2.5 \mu \mathrm{m}$ are removed from the air stream by a cyclone before entering the denuder, and smaller particles pass through without deposition on the reactive inner surface under the proper flow rate conditions $\left(101 \mathrm{~min}^{-1}\right)$. After the $2 \mathrm{~h}$ sampling period, a one hour analysis procedure begins by flushing the 1130 and 1135 systems with mercury free air. The PBM and GOM collected on the quartz filter and annular denuder, respectively, were thermally decomposed (at 800 and 500 ${ }^{\circ} \mathrm{C}$ respectively) into the mercury free air stream and detected as GEM. During the campaign denuders were recoated and replaced weekly. The Tekran 2537A analysers were calibrated on a daily basis using the internal permeation tubes. The permeation tube in each of the Tekran 2537A instruments was calibrated just prior to the study as described in Landis et al. (2002) using a Tekran model 2505 primary calibration unit. The detection limit for GOM and PBM under the operating conditions used was less than $2 \mathrm{pg} \mathrm{m}^{-3}$.

\section{Results and Discussion}

During both the autumn 2004 and 2007 campaigns events with high values of GOM and/or $\mathrm{Hg}$ associated with particulates (PBM), that could be linked to probable anthropogenic emission source areas, were observed. Maximum values equal to 62.9 and $97.8 \mathrm{pg} \mathrm{m}^{-3}$ for GOM, and equal to 50.9 and $77.5 \mathrm{pg} \mathrm{m}^{-3}$ for PBM, were recorded during 2004 and 2007 cruise campaigns, respectively. During the summer campaign however, the by now rather familiar diurnal variation of GOM concentration, with maxima around midday, was also observed (Sprovieri et al., 2003; 2008; 2010). Again there were events with peak in GOM (Max: 39.9) and in PBM (Max: 9.11) concentrations. The origin of these events was investigated using back trajectory simulations and with also the support of the Navy Aerosol Analysis and Prediction System (NAAPS) predicting the distribution of tropospheric aerosols and its surface concentration in terms of dust, sulphate or smoke concentration (Naval Research 
Laboratory, 2010). Results showed that for all the events during which high $\mathrm{Hg}$ species concentrations were encountered the air-mass being sampled had passed in the previous $24 \mathrm{~h}$ near areas associated with major industrial installations. Investigations were also carried out with reference to the period in which the $R . V$. Urania stopped close to those main Italian industrial Contaminated Sites that were reached during the 2004, 2005 and 2007 oceanographic campaigns (see Fig. 2). The GEM values, recorded close to the Contaminated Sites, ranged from $0.9 \mathrm{ng} \mathrm{m}^{-3}$ (min for Trieste) to $4.0 \mathrm{ng} \mathrm{m}^{-3}$ (Max for Milazzo) during both the autumn 2004 and 2007 cruise campaigns and from 1.1 $\mathrm{ng} \mathrm{m} \mathrm{m}^{-3}$ (min for Falconara Marittima) to $4.6 \mathrm{ng} \mathrm{m}^{-3}$ (Max for Trieste)) during the summer 2005 campaign. Mean values, averaged over each single stop-period, were otherwise observed to range from $1.3 \mathrm{ng} \mathrm{m}^{-3}$ (mean for Trieste) to $3.1 \mathrm{ng} \mathrm{m}^{-3}$ (mean for Falconara Marittima) during both the autumn 2004 and 2007 cruise campaigns and from $1.5 \mathrm{ng} \mathrm{m}^{-3}$ (mean for Bari) to $3.6 \mathrm{ng} \mathrm{m}^{-3}$ (mean for Trieste) during the summer 2005 campaign.

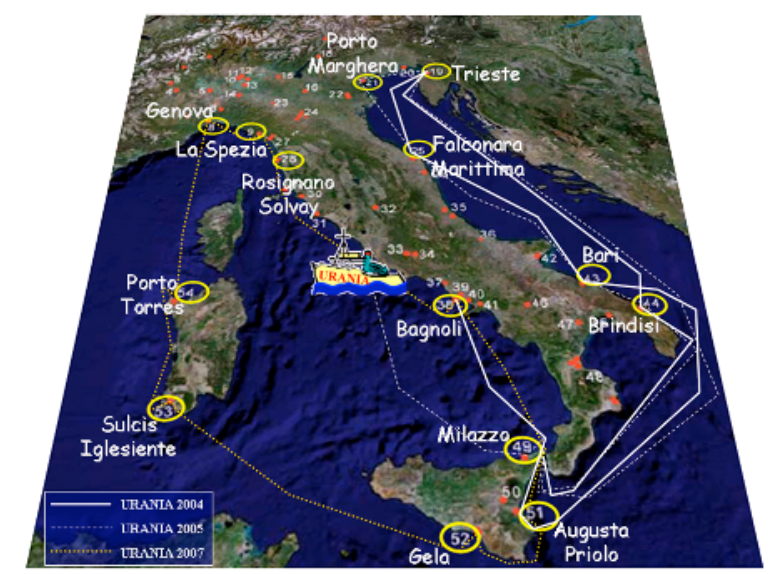

Fig. 2. The R.V. Urania cruise paths during the 2004, 2005 and 2007 Mediterranean oceanographic campaigns.

These obtained values, particularly those referring to the autumn campaigns, result rather comparable to those recorded within the single one work that currently is published in the scientific literature and that refers to ambient air mercury measurements close to an Italian Contaminated Site. This study, reported in (Gibičar et al., 2009), involved the contaminated area of Rosignano Solvay for which the measured GEM values resulted in a range from 2.8 to $4.2 \mathrm{ng} \mathrm{m}^{-3}$ in winter and from 8.0 to $8.7 \mathrm{ng} \mathrm{m}^{-3}$ in summer period.

\section{Conclusion}

Additional research is required to reduce uncertainty in mercury emissions estimates (HTAP Assessment Report, 2010; Pacyna et al., 2006; Pirrone et al., 2010a) with particular emphasis for Large Industrial Point Source (Ferrara et al., 1992; Gronlund et al., 2005). These uncertainties is critical since it affects model and policy development and also human welfare. Additionally, the ability to determine the accuracy of current models is severely limited by the lack of mercury measurements that could account for a better emission source characterisation. Delineation of mercury "hot spots", as those presented in this work, even if should be considered as an exploratory study, holds a relevant interest in that it fills the observation gaps over atmospheric mercury measurements from contaminated sites. The resulting improved knowledge would lead to realistic risk assessments and efficient mitigation efforts.

\section{Acknowledgements}

The authors acknowledge the NOAA Air Resources Laboratory (ARL) for provision of the HYSPLIT4 transport and dispersion model, and of the READY website (http://www.arl.noaa.gov/ready.html), whose results are used in this publication.

\section{References}

Ferrara, R., Maserti, B.E., Edner, H., Ragnarson, P., Svanberg, S., Wallinder, E., 1992. Mercury emissions to the atmosphere from a chlor-alkali complex measured by the Lidar technique. Atmospheric Environment 26A, 1253-1258.

Gibičar D., Horvat M., Logar M., Fajon V. Falnoga I., Ferrara R., Lanzillotta E., Ceccarini C., Mazzolai B., Denby B., Pacyna J., 2009. Human exposure to mercury in the vicinity of chlor-alkali plant. Environmental Research 109, 355-367.

Gronlund, R., Sjoholm, M., Weibring, P., Edner, H., Svanberg, S., 2005. Elemental mercury emissions from chlor-alkali plants measured by lidar techniques. Atmos. Envir. 39, 7474-7480.

HTAP 2010 Assessment Report - Emissions and Projections, Tech. Rep. Chapter B3, LRTAP - Task Force on Hemispheric Transport of Air Pollutants, http://htap.icg.fz-juelich.de/ data/ChapterB3, 2010c.

Landis, M. S., Stevens, R. K., Schaedlich, F., and Prestbo, E. M.: Development and Characterization of an Annular Denuder Methodology for the Measurement of Divalent Inorganic Reactive Gaseous Mercury in Ambient Air, Environ. Sci. Technol., 36, 3000-9, doi:10.1021/es015887t, 2002.

Pacyna, E.G., Pacyna, J.M., Fudala, J., Strzelecka-Jastrzab, E., Hlawiczka, S., Panasiuk, D., 2006. Mercury emissions to the atmosphere from anthropogenic sources in Europe in 2000 and their scenarios until 2020. Sci. Total Env. 370, 147-56.

Pirrone N., Cinnirella S., Feng X., Finkelman R. B., Friedli H. R., Leaner J., Mason R., Mukherjee A. B., Stracher G. B., Streets D. G. and Telmer K.: Global mercury emissions to the atmosphere from anthropogenic and natural sources. Atmos. Chem. Phys., 10, 5951-5964, 2010b.

Sprovieri, F., Pirrone, N., Gårdfeldt, K., and Sommar, J.: Mercury speciation in the Marine Boundary Layer along a $6000 \mathrm{~km}$ cruise path around the Mediterranean Sea, Atmos. Environ., 37, 63-71, 2003

Sprovieri, F. and Pirrone, N.: Spatial and temporal distribution of atmospheric mercury species over the 
Adriatic Sea, Environmental Fluid Mechanics, 8, 117-128, doi:10.1007/s10652-007-9045-4, 2008.

Sprovieri F., Hedgecock I. M. and N. Pirrone: An

investigation of the origins of reactive gaseous mercury in the Mediterranean marine boundary layer. Atmos. Chem. Phys., 10, 3985-3997, 2010. 